Dion et al.

5. Levy DA, Slaton JW, Swanson DA, et al. Stage specific guidelines of surveillance after radical nephrectomy for local renal cell carcinoma. J Urol 1998;159:1163-7.

6. Stephenson AJ, Chetner MP, Rourke K, et al. Guidelines for the surveillance of localized renal cell carcinomo based on the patterns of relapse after nephrectomy. J Urol 2004;172:58-62.

7. Skolarikos $A$, Alivizatos $G$, Laguna $P$, et al. A review of follow-up strategies for renal cell carcinoma after nephrectomy. Eur Urol 2007;51:1490-1501.

8. Liungberg B, Alamdari FI, Rasmuson T, et al. Follow-up guidelines of nonmetastatic renal cell carcinoma based on the occurrence of metastases after radical nephrectomy. BJU Int 1999;84:405-11.

9. Kassouf W, Siemens R, Morash C, et al. Follow-up guidelines after radical or partial nephrectomy for localized and locally advanced renal cell carcinoma. Can Urol Assoc J 2009;3:73-6.

10. Greene FL, Page DL, Fleming ID, Fritz A, editors. American Joint Committee on Cancer. Cancer Staging Manual, $6^{\text {th }}$ ed. New York; Springer-Verlag; 2002
11. Sharma K, Das S, Mukhopadhyay A, et al. Economic cost analysis in cancer management and its relevance today. Indian J Cancer 2009;46:184-19.

12. Knox S. Health economic decision making in Europe - a new priority for breast cancer advocacy. Breast 2009:18:71-2.

13. Koerkamp GB, Wang YC, Hunink MG. Cost-effectiveness analysis for surgeons. Surgery 2009;145:616-22.

Correspondence: Dr. Stephen E. Pautler, Division of Urology, St. Joseph's Hospital, 268 Grosvenor St., London, ON N6A 4V2; fax: 519-646-6037; stephen.pautler@sihc.london.on.ca

\title{
Rational or rationing? Justifying follow-up after management of kidney cancer
}

\author{
D. Robert Siemens, MD, FRCSC
}

See related article on page 322.

Y ou have just finished meeting with your 46-year-old patient, a mother of 3 school-aged children, now 4 weeks after a successful nephrectomy for a T1 N0 M0 conventional cell renal cell carcinoma (RCC). She has done well and after much reassurance you have made arrangements to see her next year for a chest X-ray. Have you caught yourself questioning whether your patient or her family feels this is adequate? You likely have felt obliged to convey to them that this relatively conservative surveillance schedule is based on sound new follow-up guidelines from our national association. On second thought, you think, this was a 6-cm kidney cancer that required significant intervention, so maybe an extra visit and further imaging would be reassuring to all concerned?

From a consumer point of view, well-communicated, timely and empathetic postoperative follow-up after cancer surgery surely is an indicator of good quality of care. Several authoritative bodies (and many individual experts) agree with this and have suggested frequent follow-up schedules for several urologic conditions. ${ }^{1,2}$ Perhaps you will order that computed tomography $(\mathrm{CT})$ for the chest and abdomen for your patient in 9 months despite the suggested guidelines?

The CUA guidelines on follow-up after radical or partial nephrectomy attempt to bring "clarity and guidance to the practicing urologist" given that there is no consensus on which investigations should be performed and at what intervals. ${ }^{3}$ The goals of any postoperative follow-up schedule for neoplastic disease would be to provide patient reassurance, functional review after a surgical procedure (arguably more relevant after the reconstruction with cystectomy or prostatectomy) and early detection of recurrent disease, for which intercession would lead to some clinical benefit. Unfortunately, the current recommendations of follow-up after nephrectomy rely only on observational and case studies to determine the potential benefit of early detection of recurrence. ${ }^{4}$ Given the lack of any high level of evidence, the CUA guidelines provide a uniquely Canadian perspective, balancing these goals of follow-up with the limited evidence regarding the benefit of frequent imaging, especially in a universal health care system with finite resources.

The article by Dion and colleagues clearly demonstrate the direct cost-savings of adherence to the CUA guidelines for follow-up after radical nephrectomy compared to their 
previous institutional standards. ${ }^{5}$ The theoretical cost savings after 6 years of surveillance approach $26 \%$ (or $\$ 46,806$ ) for the 75 patients in their cohort. These authors should be congratulated for their critical review of their practice, including their insights of the subsequent investigations stimulated by false-positive findings common in routine follow-up imaging, which approached $10 \%$ of all incurred costs. Most us will identify with those advocating caution regarding the apparent "epidemic" of imaging which lead to the "epidemic of treatments that inevitably follow." ${ }^{\prime \prime}$ The age-adjusted, per capita rate of diagnostic imaging (CT, magnetic resonance imaging and ultrasound) in Ontario has increased $18 \%$ per year over the last decade. ${ }^{7}$

Dion and colleagues only reviewed their direct costs of follow-up; a detailed assessment of indirect and opportunity costs were well beyond their scope and a true cost-efficacy analysis would likely be unfeasible given the assumptions required regarding the clinical benefit of detecting early disease recurrence of RCC (generally level 3 evidence). However, the very tangible cost-savings described in this article, based simply on following thoughtful peer-reviewed guidelines, seem to underscore the imperative of the CUA to continue developing and advocating for sound and reasonable recommendations balancing rational care with careful rationing.

Associate Professor of Urology, Department of Urology, Queen's University, Kingston, ON
Competing interests: None declared.

This paper has been peer-reviewed.

Correspondencees: Dr. D. Robert Siemens, Department of Urology, Queen's University, 76 Stuart St., Kingston 0N K7L 2V7; siemensi@kgh.kari.net

\section{References}

1. Gagliardi AR, Fleshner N, Langer B, et al. Development of prostate cancer quality indicators: a modified Delphi approach. Can J Urol 2005;12:2808-15.

2. Cagiannos I, Morash C. Surveillance strategies after definitive therapy of invasive bladder cancer. Can Urol Assoc J 2009;3:S237-42.

3. Kassouf W, Siemens R, Morash C, et al. Follow-up guidelines after radical or partial nephrectomy for localized and locally advanced renal cell carcinoma. Can Urol Assoc J 2009;3:73-6.

4. Skolarikos A, Alivizatos $G$, Laguna $P$, et al. A review of follow-up strategies for renal cell carcinoma after nephrectomy. Eur Urol 2007;51:1490-501.

5. Dion $M$, Martínez $C H$, Williams AK, et al. Cost analysis of two follow-up strategies for localized kidney cancer: a Canadian cohort comparison. Can Urol Assoc J 2010;5:322-6.

6. Welch H, Schwartz L, Woloshin S. What's making us sick is an epidemic of diagnoses. New York Times. January 2, 2007

7. Hall S, Walker H, Schneeberg A, et al. Increasing detection or increasing incidence in thyroid cancer. World I Surg 2009;33:2567-71.

\section{ERRATUM}

CUAJ would like to apologize to Dr. Venu Chalasani, Dr. Carlos H. Martinez, Dr. Darwin Lim, Dr. Geoffrey R. Wignall, Dr. Larry Stitt and Dr. Stephen E. Pautler for the error in the August 2010 issue of CUAJ. Due to a printing error, the first page of their article entitled "Impact of body mass index on perioperative outcomes during the learning curve for robotassisted radical prostatectomy" in the print edition was not printed. We sincerely apologize to the authors and to our readers. The complete version of the article appears online. 